\title{
Unison of movements in football players with different nervous systems
}

1. Candidate of pedagogical sciences, associate professor, Department of Physical Education, Faculty of Physical Culture and Sports, the Vyatka State University, Kirov, Russia.

\begin{abstract}
SUMMARY
In this study, we investigated the effect of typological features of nervous system properties on the ability to unite the movements of young football players. A total of 36 young football players aged 11-12 years participated in this experiment. Of them, 18 were engaged in an experimental differentiated method, which is based on using the same exercise and methods for developing the ability to unite movements but with different load components; for players with a strong nervous system ( 9 children), the load was intensive, but for players with a weak nervous system (9 children) - the load was volumetric. The other 18 athletes made up the control group. After 8 months of the experiment, we observed positive changes in terms of the ability to unite movements in young football players. In the control group, these changes were not significant $(P>0.05)$. In the experimental group studied according to a special method, the indicators changed considerably. The performance of football players with a strong nervous system improved from $6.4 \pm 0.2 \mathrm{~s}$ to $5.7 \pm 0.1 \mathrm{~s}$ $(P<0.05)$, and for football players with a weak nervous system from $6.2 \pm 0.2 \mathrm{~s}$ to $5.6 \pm 0.2 \mathrm{~s}(P<0.05)$. The study proved the effectiveness of the use of the typological properties of the nervous system as a differentiated method for developing the ability to unite movements in young football players. This approach allows for the improvement of the quality of technical training of young athletes.
\end{abstract}

KEYWORDS: Biotypology. Football. Nervous system. Movement.

\section{INTRODUCTION}

To achieve a high level of technical skill, it is necessary to train hard since early childhood. The technical training of the athlete is responsible for the coordination ability ${ }^{1-3}$.

There are several classifications of coordination abilities ${ }^{4-6}$. For footballers, the most important are: the ability to adapt and rebuild motor actions, kinesthetic differentiation parameters of the movements, spatial orientation, the ability to unite movements, respond quickly, sense the rhythm of movements and balance. One of the leading coordination abilities for football players is the ability to unite movements, which is manifested in the con- nection of individual actions into a coherent motor combination ${ }^{7}$.

The sensitive period for the development of coordination abilities is during primary school age (8-12 years). The ability to unite movements is better developed at the age of 11-12 years ${ }^{8-10}$.

An individual approach is one of the most important principles of general and special pedagogy. The essence of the individual approach is to tailor it to the athletes. An individual approach is aimed at creating favorable conditions for the training and development of athletes, based on their individual capabilities; it is a differentiated approach to coach

DATE OF SUBMISSION: 27-May-2018

DATE OF ACCEPTANCE: 20-Jun-2018

CORRESPONDING AUTHOR: Georgy Polevoy

E-mail: gera_lider1@mail.ru 
the individual characteristics of a group of athletes during the training process. The implementation of a differentiated approach streamlines the construction of the long-term training of young athletes, understands better the factors limiting the manifestation of motor abilities and implements reserve possibilities of functional systems of the organism of young athlete's ${ }^{11,12}$.

Athletes can be dived into groups based on a variety of characteristics, such as physical types, functional indicators, technical training and so on ${ }^{13-15}$.

A little-known but effective criteria for grouping athletes are typological peculiarities of nervous system properties of athletes, namely, strength and weakness of the nervous system in the process of excitation ${ }^{16,17}$.

Studies that confirm the efficacy of a differentiated approach based on the typology of athletes have been conducted in different sports - athletics, table tennis, basketball ${ }^{18-20}$. However, in football, there have been no such researches.

This study aims to investigate the impact of typological characteristics of the nervous system (nervous system strength) on the ability to unite movements of football players.

Our hypothesis is that the method for developing players' ability to unite movements based on the typological differentiation of athletes will improve their outcome in the sport.

\section{Objectives of the study:}

1) To determine the level of development of the ability to unite movements in football players aged 11-12 years;

2) Develop an experimental method to develop the ability to unite football player's movements 11-12, based on the differentiation of loads and the nervous system strength of young athletes;

3) To study the effect of differentiated methods on football sporting activities for players aged 11-12 years.

\section{MATERIALS AND METHODS}

The study used methods:

1) Pedagogical experiment

a) Determining the strength of the nervous system of football players;

b) Determining the level of development of the ability to unite movements in young athletes.

2) Methods of mathematical and statistical processing of information.

\section{Subjects}

We included in the pedagogical experiment young football players aged 11-12 years who train at sports school nº5, Kirov.

\section{Research procedure}

Before the start of the study, 36 football players aged 11-12 years were randomly selected. Taking into account the nervous system strength, they were divided into the experimental group (EG) and control group (CG), each with a total of 18 players divided into two subgroups, one with a strong nervous system and the other with a weak one ${ }^{21}$.

During the sports year (8 months), the football players of the EG were engaged in experimental methods, and the ones in the KG followed the standard program of the sports schools ${ }^{22}$. All the athletes trained 3 times a week. Each workout lasted 90 minutes. There was a total of 112 training sessions in each group.

\section{Control tests}

1. The strength of the nervous system was initially determined using the "Tapping-test" method.

The test consists of: an A4 sheet of paper divided into six squares (three squares in two rows). The coach gives the signal. Athletes put dots in 1 square for 5 seconds. Every 5 seconds, the athlete needs to move on to the next square. The goal is to put as many dots as possible in each square. When the sixth square is reached, the exercise ends. The results: the number of dots in each square is counted to assess the performance and determine the type of nervous system strength ${ }^{23}$.

2. The football players' ability to unite movements is determined using the "Slalom with dribbling two balls" test.

The method of the test: three sticks are set over a $10 \mathrm{~m}$ straight-line. The first stick is located at a distance of 2.5 meters from the start line. At the coach's signal, the athlete covers the distance between the sticks moving the two balls at the same time using the feet (illustrations 1).

The results: the running time between the sticks, while moving the two balls, with an accuracy of 0.01 seconds ${ }^{24}$.

3. Friendly match between the EG and KG teams. The match results are used to objectively estimate the young football players' level of proficiency and ability to unite movements. This is used to validate the effectiveness of the experimental procedure. 
ILLUSTRATIONS 1. SLALOM WITH TWO DRIBBLING BALLS

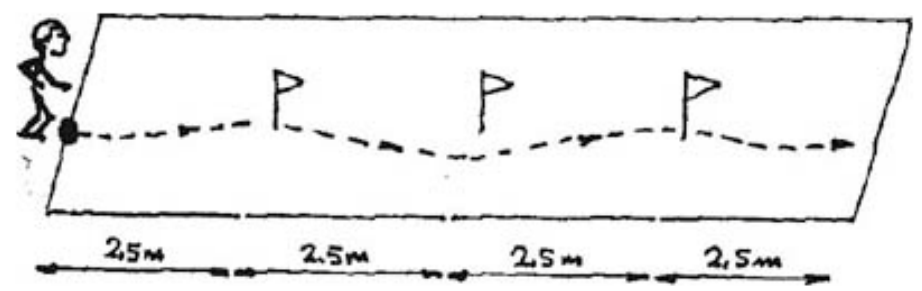

Feature training in the EG:

After the usual warm-up (10-15 minutes), football players of the EG carried out exercises to develop the ability to unite movements in different subgroups, for 20 minutes.

1) Means (physical exercises) - moving hands during dribbling, blowing a ball while jumping, using exercises for general physical training with technical elements, maintaining two balls at the same time and other exercises ${ }^{7,25}$.

2) Methods - repeated (the main method), interval, game, and competitive methods ${ }^{26}$.

3) Methodical receptions - new exercises, a complication of the previous exercises, change of speed and direction of the movement when performing physical exercises ${ }^{26}$.

4) Load components were the main difference in the training of young football players with strong and weak nervous systems. For football players with a strong nervous system, the load was intensive, while for football players with a weak nervous system the load was volume ${ }^{19}$.

At the same time, the intensity of the load increased by increasing the number of exercises and reducing rest times. The volume load was increased by increasing the number of repetitions and rest intervals.

The intensity of the exercise was set at 150-170 beats/min for both groups.

The duration of the exercise for football players with a strong nervous system was of 25-30 seconds, and 35-40 seconds for the weak ones.

The resting time for both groups lasted until full recovery, the character of recreation was passive.

The number of repetitions of the same exercise for football players with a strong nervous system was 3-5 times with 6-8 series; for weak ones, it was 4-6 times with 7-10 series.

\section{Statistical analysis}

The mathematical and statistical processing of the results of the pedagogical experiment were carried out using a parametrical criterion (t-student) ${ }^{27}$. The correlation analysis was made using BioStat 2009 software. The result was considered significant at a value $\mathrm{P}<0,05^{21}$.

\section{STATISTICAL RESULTS}

Before the start of the pedagogical experiment, there was a friendly match between the EG and KG teams. The match had a final score of 0-0. During the game, it was objectively visible that football players in both groups moved equally and had equal ability to unite movements.

No significantly relevant indicators of the football players of the EG and KG and also in the subgroups was revealed $(\mathrm{P}<0,05)$.

The results of the "Slalom with maintaining two balls" test for all subgroups (from 6.9 to $6.2 \mathrm{c}$ ) correspond to the average level of development of the ability to coordinate movements in football players aged 11-12 years ${ }^{28}$. The indicators of the ability to unite movements in football players aged 11-12 years are presented in table 1.

From table 1, it is visible that, after the end of the pedagogical experiment in both groups and subgroups, there were positive changes in the results of the "Slalom with maintaining two balls" test.

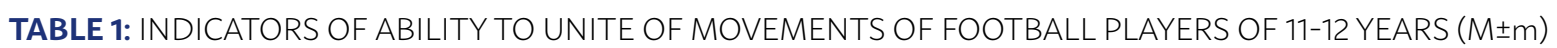

\begin{tabular}{|c|c|c|c|c|c|c|c|c|}
\hline \multirow[b]{2}{*}{ Indicators } & \multirow{2}{*}{$\begin{array}{l}\text { Strength of } \\
\text { the nervous } \\
\text { system }\end{array}$} & \multicolumn{3}{|c|}{$\mathrm{EG}$} & \multicolumn{3}{|c|}{ CG } & \multirow[b]{2}{*}{$P(2-5)$} \\
\hline & & $\begin{array}{c}\text { Before } \\
1\end{array}$ & $\begin{array}{c}\text { After } \\
2\end{array}$ & $\begin{array}{l}P \\
3\end{array}$ & $\begin{array}{c}\text { Before } \\
4\end{array}$ & $\begin{array}{l}\text { After } \\
5\end{array}$ & $\begin{array}{l}P \\
6\end{array}$ & \\
\hline \multirow{3}{*}{$\begin{array}{l}\text { Slalom with } \\
\text { maintaining } \\
\text { two balls (s) }\end{array}$} & Strong & $6,4 \pm 0,2$ & $5,7 \pm 0,1$ & $\begin{array}{l}t=2,88 \\
P<0,01\end{array}$ & $6,9 \pm 0,3$ & $6,6 \pm 0,2$ & $\begin{array}{l}t=1,11 \\
P>0,05\end{array}$ & $\begin{array}{l}t=3,74 \\
P<0,05\end{array}$ \\
\hline & Weak & $6,2 \pm 0,2$ & $5,6 \pm 0,2$ & $\begin{array}{l}t=2,18 \\
P<0,05\end{array}$ & $6,6 \pm 0,3$ & $6,3 \pm 0,3$ & $\begin{array}{l}t=0,51 \\
P>0,05\end{array}$ & $\begin{array}{l}t=2,50 \\
P<0,01\end{array}$ \\
\hline & & $\begin{array}{l}t=0,62 \\
P>0,05\end{array}$ & $\begin{array}{l}t=0,38 \\
P>0,05\end{array}$ & & $\begin{array}{l}t=0,94 \\
P>0,05\end{array}$ & $\begin{array}{l}t=0,67 \\
P>0,05\end{array}$ & & \\
\hline
\end{tabular}


Young football players from the KG showed an improvement in the indicators, but not a significant one. While the indicators of athletes with a strong nervous system improved from $6.9 \pm 0.3 \mathrm{~s}$ to $6.6 \pm 0.2$ $\mathrm{s}(\mathrm{P}>0,05)$, that of athletes with a weak nervous system improved from $6.6 \pm 0.3 \mathrm{~s}$ to $6.3 \pm 0.3 \mathrm{~s}(\mathrm{P}>0,05)$.

The indicators of football players aged 11-12 years who trained using differentiated methods considerably improved. The indicators of athletes in the EG with a strong nervous system improved from $6.4 \pm 0.2$ $\mathrm{s}$ to $5.7 \pm 0,1 \mathrm{~s}(\mathrm{P}<0,05)$, and that of athletes with a weak nervous system improved from $6.2 \pm 0.2 \mathrm{~s}$ to $5.6 \pm 0.2 \mathrm{~s}(\mathrm{P}<0,05)$. Such indicators correspond to a high level of development of the ability to unite movements in football players at the age of 11-12 years ${ }^{28}$.

After the pedagogical experiment, the EG team and the KG team played a friendly match again. The match ended with the victory of the EG team, with a score of 6-1. During the game, football players from the EG team looked much quicker, with more technical skills, better ability to unite movements and their actions were more effective than that of the football players from the KG team. The result of a match allows judging efficiency of the experimental method.

\section{DISCUSSION}

There is no doubt that coordination abilities are the basis of an athlete's technical skills, especially in sports such as football ${ }^{1-3}$.

One of the primary coordination abilities for football players is the ability to unite movements ${ }^{4-6}$.

However, research directed at studying the coordination abilities of football players has not been able to show a complete picture of the training process for athletes. Recommendations made are, as a rule, generic; the means and methods for developing coordination abilities are defined, as well as load parameters, for all football players, regardless of their type of nervous system or other criteria ${ }^{7}$.

In our research, we detail specific means, methods and load components that should be used in the training process for young football players with different nervous systems.
Our research confirms opinions on the effectiveness of using a differentiated approach during the training process of young athletes. Such an approach takes advantage of the athletes' specific organism, thus having a more positive influence and more effective results in developing their abilities ${ }^{11,12}$.

dDuring the experiment, based on our results we defined concrete recommendations for working with young football players aged 11-12 years with different typological features of the manifestation of nervous system properties.

Our hypothesis that the method to develop the ability to unite movements in football players based on differentiating athletes based on typological signs could improve their results in a game was completely proved.

\section{CONCLUSION}

The experimental method of using different approaches to develop the ability to unite movements in football players aged 11-12 years based on typological features of the manifestation of athletes' nervous system properties had a positive and progressive impact on football players in the EG $(\mathrm{P}<0,05)$.

The indicators of football players from the KG who were trained according to the usual program also improved, but not considerably $(\mathrm{P}>0,05)$.

The results of a friendly match at the end of the pedagogical experiment confirmed the effectiveness of the differentiated method. The EG team victory with a score of 6-1 shows that football players from the KG team were technically weaker, with a slower ability to unite movements during the game, unlike football players from the EG team.

This research attracts great interest from trainers who work in sports like football. The research described in detail means, methods, and loads for football players with different nervous system strength. It also determined effective tests to determine nervous system strength during the process of excitation and the level of development of the ability to unite movements in players aged 11-12 years. Such tests can be used for working with young athletes. 


\section{RESUMO}

Neste estudo, investigamos o efeito das características tipológicas das propriedades do sistema nervoso sobre a capacidade de união dos movimentos de jovens jogadores de futebol. Trinta e seis jovens jogadores de futebol de 11 e 12 anos participaram na experiência pedagógica. Dezoito jogadores de futebol estavam envolvidos na metodologia experimental diferenciada, que é baseada no uso de um mesmo exercício e métodos de desenvolvimento da capacidade de unir os movimentos, mas diferentes componentes da carga; para os jogadores com um sistema nervoso forte (nove garotos), a carga foi intensa, mas, para jogadores com um sistema nervoso fraco (nove garotos), a carga foi volumétrica. Os outros 18 atletas compõem o grupo de controle. Em oito meses de experiência pedagógica houve mudanças positivas em termos da capacidade de unir o movimento de jovens jogadores de futebol. No grupo controle, essas alterações não foram significativas $(P>0,05)$. No grupo experimental estudado de acordo com uma metodologia especial, os indicadores mudaram consideravelmente. Os jogadores de futebol com um sistema nervoso forte melhoraram a performance de 6,4 $40,2 \mathrm{~s}$ para 5,7 $\pm 0,1 \mathrm{~s}(P<0,05)$, e os jogadores de futebol com um sistema nervoso fraco, de 6,2 $\pm 0,2 \mathrm{~s}$ para 5,6 $\pm 0,2 \mathrm{~s}(P<0,05)$. O novo estudo comprovou a eficácia da utilização das propriedades tipológicas do sistema nervoso como um método diferenciado de desenvolver a capacidade de unir os movimentos de jovens jogadores de futebol. Esta abordagem permite a melhoria da qualidade da formação técnica dos jovens atletas.

PALAVRAS-CHAVE: Biotipologia. Futebol americano. Sistema nervoso. Movimento.

\section{REFERENCES}

1. Issurin VB, Lyakh VI. Coordination abilities of athletes: basics of manifestation, evaluation and elucidation: a review. J Athl Enhanc. 2017;6(2).

2. Nikitin AV. Coordination abilities of young football players-goalkeepers in their structure of motor abilities. Uchenye zapiski universiteta imeni P.F. Lesgafta. 2011;81:108-12.

3. Sadowski J, Wolosz P, Zielinski J, Niznikowski T, Buszta M. Structure of coordination motor abilities in male basketball players at different levels of competition. Polish | Sport Tourism. 2014;21(4):234-9.

4. Alexandrova VA, Shian VV. Some types of the coordination abilities of the athlete-dancers. Uchenye zapiski universiteta imeni P.F. Lesgafta. 2014;112:12-7.

5. Dveyrina OA. Coordination capacities: definition, classification, forms. Uchenye zapiski universiteta imeni P.F. Lesgafta. 2014;35:35-8.

6. Martynova AS. Development of the general and specific coordination abilities among the badminton-players at the age of 8-11 years old. Uchenye zapiski universiteta imeni P.F. Lesgafta. 2011;72:132-5.

7. Lyakh VI, Sadowski J, Witkowski Z. Development of coordination motor abilities (CMA) in the system of long-term preparation of athletes. Polish J Sport Tourism. 2011;3:187-97.

8. Feoktistov MF. Periods of sensitivity of development of physical abilities among various contingents of pupils at average school age. Uchenye zapiski universiteta imeni P.F. Lesgafta. 2010;62:118-20.

9. Karpeev AG. Long-term strategy of sports and technical preparation with due regard for age peculiarities of motor coordination development. Uchenye zapiski universiteta imeni P.F. Lesgafta. 2008;38:35-9.

10. Oskolkov VA, Kshinin II. Coordination abilities in structure of motor possibilities of the young boxers with various tactical manners of the duel conducting. Uchenye zapiski universiteta imeni P.F. Lesgafta. 2011;77:121-4.

11. Bakulev SE, Dveyrina OA, Savvina AS. Differentiated approach to the determination of major sports coordination abilities boxer. Uchenye zapiski universiteta imeni P.F. Lesgafta. 2006;20:3-9.

12. Solomatin VR. Individual approach in elaborating the many-year training of young male swimmers. Uchenye zapiski universiteta imeni P.F. Lesgafta. 2010;61:103-7.

13. Alagizov AV. Differentiated methodology for training of children aged $10-$ 11 years old engaged in winter polyathlon considering their morphological and functional parameters. Uchenye zapiski universiteta imeni P.F. Lesgafta. 2012;92:7-10.
14. Khasawneh A. Prevailing somatotypes and their contribution rate to the coordination abilities among the students of the physical education college. Physical Educ. 2015;5(3):176-87.

15. Sonina NV, Rodin AV. The differentiated approach to technique-tactical preparation of young basketball players of 15-16 years old in view of game role. Uchenye zapiski universiteta imeni P.F. Lesgafta. 2008;38:84-6.

16. Nebylitsyn VD. Structure of the basic properties of the nervous system. Fundamental properties of the human nervous system. 1972:9-22.

17. Strelau J. Pavlov's nervous system typology and beyond. Moscow: Individual differences and psychopathology; 1983. p.139-54.

18. Kostyunina LI, Kiryanova LA, Anisimova YA. Special features of the manifestation of nervous system typological properties among sprint track and field athletes. Uchenye zapiski universiteta imeni P.F. Lesgafta. 2010;62:38-42.

19. Makarov YM, Hussain A-T. Typological profile of person properties of the basketball players aged 16-18 years old depending on the style of game activity. Uchenye zapiski universiteta imeni P.F. Lesgafta. 2011;73:122-4.

20. Serova LK, Voronov AA. Dependence of individual style of activity in table tennis on typological properties of the identity of athletes. Uchenye zapiski universiteta imeni P.F. Lesgafta. 2013;95:140-3.

21. David FN, Cramer H. Mathematical methods of statistics. Biometrika. 1947;3/4(34):374

22. Godik MA. Football: a model of training program of sports training for youth sports schools, specialized youth school of Olympic reserve. Moscow: Soviet Sport;2011. p.1-160.

23. Raigorodskiy DJ. Practical psychodiagnostics. Methods and tests. Method of express-diagnostics of the properties of the nervous system by E. P. Ilyin's psychomotor measures (Tapping-test). Samara: Publishing house: Bakhrakh-M;2001.

24. Ljach VI, Vitkovski Z, Zhmuda V. Coordination abilities of soccer players. Theory and practice of physical culture. 2004;4:21-25.

25. Paramonov W. Development of abilities to rational activity in the changed conditions of young football players' training. Uchenye zapiski universiteta imeni P.F. Lesgafta. 2011;82:124-7.

26. Holodov, Zh K, Khuznetsov VS. Theory and methods of physical training and sports. Moscow: Akademia;2009.

27. Oldham J. Statistical tests (part 2): parametric tests. Nurs Sand. 1993;7(44):28-30.

28. Lyakh VI, Witkowski Z. Coordination training in football. - Moscow. Soviet Sport;2010. 